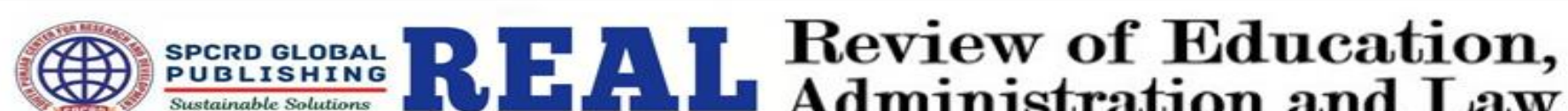 \\ Journal homepage: http://real.spcrd.org ISSN (Print): 2708-1788 ISSN (Online): 2708-3667
}

\section{The Role \& Strategies of Non Formal Education for Education Access to Marginalized Community}

\author{
${ }^{a}$ Samee Ullah, ${ }^{\text {b }}$ Faheem Ul Hassan, ${ }^{\mathrm{c}}$ Taj Muhammad \\ a Lecturer, Department of Education, Bahauddin Zakariya University, Multan, Pakistan \\ Email: sameeullah@bzu.edu.pk \\ ${ }^{\mathrm{b}}$ M.Phil Scholar, Department of Education, Bahauddin Zakariya University, Multan, Pakistan \\ ${ }^{c}$ M.Phil Scholar, Department of Education, Bahauddin Zakariya University, Multan, Pakistan
}

\begin{tabular}{l}
\hline ARTICLE DETAILS \\
\hline History: \\
Accepted 26 July 2021 \\
Available Online September 2021
\end{tabular}

\section{Keywords:}

Non Formal Education,

Strategies, Underprivileged,

Community, Punjab

\section{JEL Classification:}

I21, $P_{3} 6$

DOI: $10.47067 /$ real.v4i3.172

\section{ABSTRACT}

In Pakistan, about 22.8 million children of school going age are out of school which is very alarming situation and second highest number in the World. Major portion of these OOSCs belong to deprived, marginalized community of Pakistan. Although Pakistan has promised under article $25 \mathrm{~A}$ to educate all the boys and girls age of school going children but this yet not to be meet due to financial constraints. So to fill this gap an alternative comprehensive system is needed. Non Formal Education is recognized and understood as cost effective and flexible system to fill this gap. In context of Pakistan, despite of recognition of NFE, it has not received due attention due to lack political interest. However, in last few years it is seen progress in this sector and a Non Formal Education Policies are developed at province level e.g. Punjab Non Formal Education Policy and Sindh Non Formal Education Policy. The aim of study was to explore the strategies of Non Formal Education for education access to underprivileged community and its effectiveness in Punjab. The research was conducted in 100 NFBE schools in three districts of Punjab. It was a Quantitative survey research to explore the strategies, and impact of NFBE schools on community. Random sampling technique was used to select the sample. Data was collected from officers, teachers, students and their parents. Data was collected through Questionnaires. It was found that NFE system was imparting cost effective, affordable, flexible, inclusive education at door step of deprived and marginalized community. It was recommended to allocate the more funds to scale up NFE system to cater the all OOSC. It was also recommended to amend and implement the Literacy Act 1987.

(C) 2021 The authors. Published by SPCRD Global Publishing. This is an open access article under the Creative Commons AttributionNonCommercial 4.0

Corresponding author's email address: sameeullah@bzu.edu.pk 


\section{Introduction}

Education plays a primary role in improving individual life as well as development of country .Education reduce the poverty and increase the earning at both individual and national level. Education is vital for economic development and elimination of poverty in Pakistan. Developed countries like Finland, France, Japan, China, Canada, America, Germany, Belgium and Italy are strong-minded for their people to educational access and committed for bright future and the development of their country. To ensure free and compulsory primary education, Pakistan has also committed in its national policy .According to The Constitution of Pakistan it is the responsibility of government to provide free primary education, however this has yet to be implemented by the government.

United Nations' Millennium Development Goals (MDGs) already has set universal primary education as an international development goal. Every child (age 5-9) must complete his/her primary education, by the 2015 for all countries under the EFA declaration. But Pakistan is far behind to meet the MDGs, provision of primary education. According to EFA Global Monitoring Report (UNESCO, 2015), Pakistan is on $106^{\text {th }}$ ranking of EFA Development Index (EDI). This is alarming for Pakistan as other countries like Bangladesh, Sri Lanka and Nepal show their remarkable performance in providing access to education.

"Everyone has the right to Education. Education shall be free, at least in the elementary and fundamental stages" a declaration The Universal Declaration of Human Rights (UDHR) under the United Nations General Assembly(1948) is publically announced. Under the Article 26 it is clearly mentioned that "Elementary education shall be compulsory. Technical and professional education shall be made generally available and higher education shall be equally accessible to all on the basis of merit”. Every country is committed to provide education to their people.

Under developed countries like Pakistan is also committed to provide education free and compulsory to every child of 5 to 16 years old. The Government has not yet achieved the universal goal of increasing access to education as $\mathbf{2 2 . 8}$ million children are out of School (NEMIS, 2017). According to Census 2017, the population of Punjab is 110 million out of which 30.7 million people are illiterate; and number of out of School children is 7.5 million. Increase in population swells the magnitude that has many implications for socio- economic development, particularly to meet the growing requirements for literacy and education. According to Pakistan Economic Survey 2015-16, in Punjab, the literacy rate is 64 percent among the total population. The total population of Punjab, according to Pakistan Population Census-2017, is 110,012,442 (55,958,974 male, 54,046,759 female, and 6,709 transgender) people live in Punjab. Keeping in view the past trend; the total 10+ age population of Punjab is $\mathbf{8 5 , 8 8 1 , 0 0 9}$.

\section{Table 1 Number of children out of School by provinces/states (NEMIS 2017)}

\begin{tabular}{|l|l|}
\hline Province & OOSC \\
\hline Punjab & 10,526976 \\
\hline Sindh & $6,413,227$ \\
\hline KP & $2,384,859$ \\
\hline Balochistan & $1,911,670$ \\
\hline AJK & 591,771 \\
\hline GB & 229,734 \\
\hline FATA & 741,030 \\
\hline ICT & 45,035 \\
\hline Total & $22,844,303$ \\
\hline
\end{tabular}


Table 2: Gender Wise OOSC

\begin{tabular}{|l|l|}
\hline Gender & OOSC \\
\hline Male & $10,683,206$ \\
\hline Female & $12,161,097$ \\
\hline Total & $22,844,303$ \\
\hline
\end{tabular}

People were with low socioeconomic status and mostly labourers which have no access to formal education. Parents of NFBE School's learners worked at Brick Kiln, workshops, Farms, and other labour places. They worked for daily wages. As NFBE Schools' area was agriculture land, so mother of learners worked in farms on daily basis. Saraiki was the mother tongue of parents but few were the Urdu and Punjabi speaking community also living in this area.

BRAC (Bangladesh Rural Advancement Committee) took a Initiative in 1985 in Bangladesh to provide free quality education to underprivileged out of School children specially for girls. Initially 22 one-room based Schools were established to provide education up to class 3.It was expanded over and scale up in 2000-2001and include the five-year primary School with completion period of 4 year.

BRAC primary Schools adapt a strategy of leaner-centered as well as focus on equity, quality of learning, personality development, characteristic development, and health and team work skills. Teachers are recruited from the local community and attend 12 day training and need based training. All teachers recruited are the female. Keeping in mind need of students, School timing is flexible for children so they can work with their parent. These Schools adopt the inclusive policy as they give equal chance of providing education for all.

BRAC students also take a part in the exam "Government Shomaponi Examination" that is taken at the end of primary school. This shows the validity of BRAC students' achievement (Nath, 2002 and the Center for Education Innovations, 2014).

BRAC has established 50000 preprimary and primary Schools overall Bangladesh catering the more than 1.5 million children. These Schools are one roomed based and established within the locality of targeted children. These Schools are established as per need of children so timing of School is also accordingly. These Schools totally follow the inclusive policy as described in below. "Inclusion is a strategy of providing the equal access to educational opportunities who might be excluded or marginalized and who with physical or mental disability."

As main focus is the learners, so BRAC Schools have flexible schedules for these learners as their needs. Teachers are recruited on local level and timetable is set by involving the community. Community is also involved in establishing the School. Teaching methods and learning activities are accordingly need of learner. These Schools are for those who have never attended any School and who dropped out. After completing the course duration in BRAC Schools, children got admission in formal Schools.

The current status of OOSC in Pakistan is alarming. About 7.5 million children were out of School in Punjab. Pakistan is ranked $150^{\text {th }}$ out of 189 countries with the human development indicator (HDI) value of 0.562 (with 1 being the maximum value) reported in Human development report 2018 of 
UNDP. Pakistan like others under developed countries also faces challenges in providing educational access due to lack of resources. According to Economic Survey (2018-2019), Pakistani educational budget is 2.4 percent of total GDP, which is lower than Bangladesh and India. So in this regard researcher selects the topic for research to explore the strategies of Non Formal Education for education access to underprivileged community and its effectiveness in Punjab.

The Objectives of the study are:

1. To investigate the effectiveness of Non Formal Basic Education and its access to underprivileged community.

2. To explore the Strategies adopted by the NFBE Schools.

The main research questions of the study are:

How Non Formal Education system can become effective for educational access, especially for underprivileged community?

What strategies are adopted by Non Formal Education School for education access?

\section{Research Methodology}

Researcher selected a quantitative approach to explore the practice, strategies, viability, and effectiveness of NFBE Schools.

\subsection{Population}

1080 Teachers and concerned Administrative staff of NFBE Schools of Three districts of Punjab are the population of study.

\subsection{Sampling}

Due to Covid-19, Questionnaires were filled from teachers online and telephonically to meet the quantitative aspect of research. 100 teachers and concerned People participated in research by submitting their responses online and telephonically with the vote of thanks. This Type of data is collected from 3 districts of Punjab, Muzaffargarh, Dera Gazi Khan, Pakpattan.

\subsection{Research Tool}

A Questionnaire for this study was developed for Non Formal Education Teachers, officers, students and their parents s to collect the data.

\section{Data Analysis}

Data was analysis by calculating the mean of collected quantitative data. Analysis of quantitative data provided insights on strategies of NFBE Schools.

Several successful strategies that motivated the deprived communities towards education were recognized by research participants during the data collection. These are the followings successful strategies: 
Free of cost education

\begin{tabular}{|l|l|l|l|}
\hline Level & Value & Frequency & Mean \\
\hline Strongly Agree & 5 & 70 & \multirow{2}{*}{4.36} \\
\cline { 1 - 3 } Agree & 4 & 9 & \\
\cline { 1 - 3 } Neutral & 3 & 10 & \\
\cline { 1 - 3 } Disagree & 2 & 6 & \\
\cline { 1 - 2 } Strongly Disagree & 1 & 4 & \\
\hline
\end{tabular}

$80 \%$ respondents were agreed that NFBE School is providing free of cost education.

\section{NFBE School is providing free of cost Education}

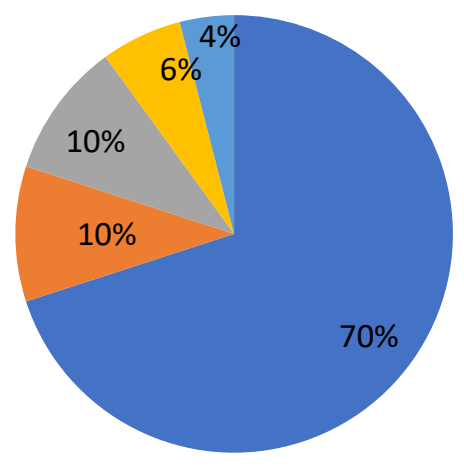

Strongly Agree: $70 \%$

Agree: $10 \%$

Neutral: $10 \%$

Strongly Disagree: 6\%

Disagree: $4 \%$

To make education access there is total free of cost education for the poor families.

Inclusive and Friendly Learning Environment

NFBE School is providing education for all type of children (Poor, disable, transgender etc) in the community in a healthy and safe environment.

\begin{tabular}{|l|l|l|l|}
\hline Level & Value & Frequency & Mean \\
\hline Strongly Agree & 5 & 91 & \multirow{2}{*}{4.88} \\
\hline Agree & 4 & 6 & \\
\cline { 1 - 2 } Neutral & 3 & 3 & \\
\cline { 1 - 2 } Disagree & 2 & 0 & \\
\cline { 1 - 2 } Strongly Disagree & 1 & 0 & \\
\hline
\end{tabular}

\section{NFBE School is accessible for all children in the community}
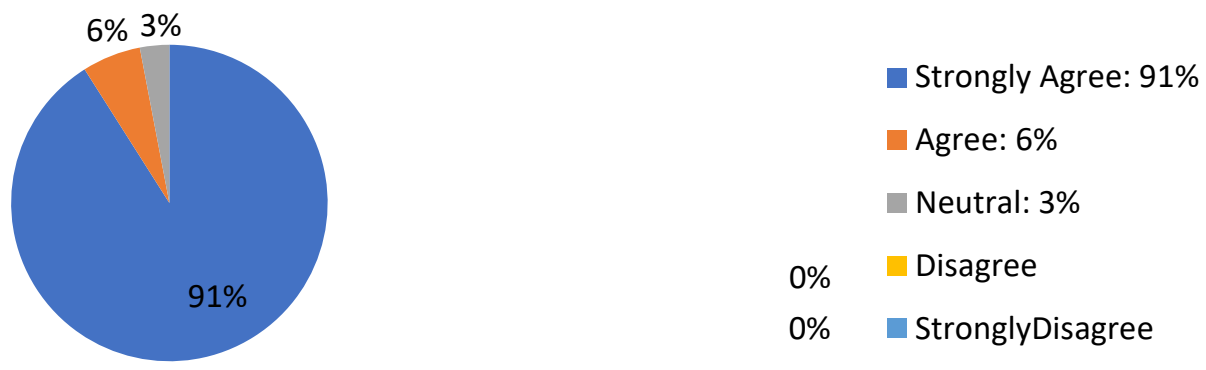
From above statement it was founded that Inclusive and child friendly learning environment was provided by NFBE School.

\section{Prefer to Female Teachers}

Is Female teacher is preferred for NFBE School

\begin{tabular}{|l|l|l|l|}
\hline Level & Value & Frequency & Mean \\
\hline Strongly Agree & 5 & 85 & \multirow{2}{*}{4.82} \\
\cline { 1 - 3 } Agree & 4 & 12 & \\
\cline { 1 - 3 } Neutral & 3 & 3 & \\
\cline { 1 - 3 } Disagree & 2 & 0 & \\
\cline { 1 - 3 } Strongly Disagree & 1 & 0 & \\
\hline
\end{tabular}

Is Female teacher is preferred for NFBE School?

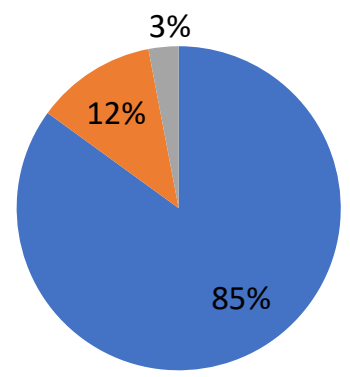

Strongly Agree: 85\%

Agree: $12 \%$

Neutral: 3\%

$0 \%$

Disagree

$0 \%$ StronglyDisagree

Proximity: NFBE School is located in the center of this community.

\begin{tabular}{|l|l|l|l|}
\hline Level & Value & Frequency & Mean \\
\hline Strongly Agree & 5 & 88 & \multirow{2}{*}{4.86} \\
\cline { 1 - 2 } & 4 & 10 & \\
Neutral & 3 & 2 & \\
\cline { 1 - 2 } Disagree & 2 & 0 & \\
\cline { 1 - 2 } Strongly Disagree & 1 & 0 & \\
\hline
\end{tabular}

NFBE School is located in the center of this community.
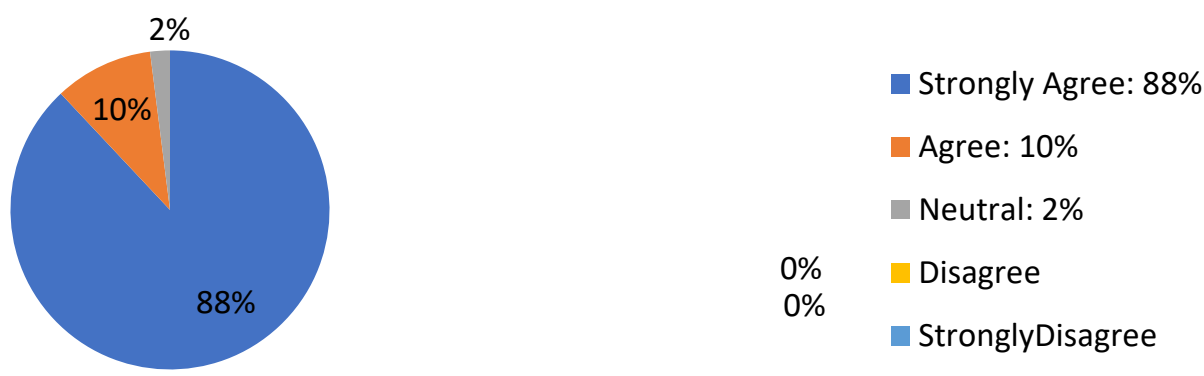
NFBE School are established at feasible sites on need-bases.

\begin{tabular}{|l|l|l|l|}
\hline Level & Value & Frequency & Mean \\
\hline Strongly Agree & 5 & 90 & \multirow{2}{*}{$4 \cdot 75$} \\
\cline { 1 - 2 } & 4 & 0 & \\
\hline Neutral & 3 & 3 & \\
\cline { 1 - 2 } Disagree & 2 & 5 & \\
\cline { 1 - 2 } Strongly Disagree & 1 & 0 & \\
\hline
\end{tabular}

\section{NFBE School are established at feasible sites on need- bases.}
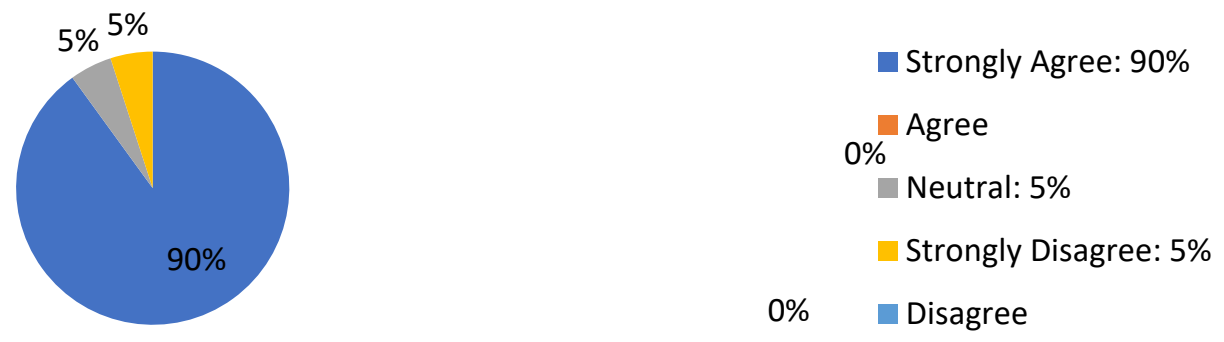

Proximity is the one the strategy being adopted by the NFBE School as an Ex-student remarks as below NFBE School is very useful alternative for those who cannot afford formal School which is far from their homes due to transport expenditure.

Flexibility: NFBE school timing is according to need of children of this community.

\begin{tabular}{|l|l|l|l|}
\hline Level & Value & Frequency & Mean \\
\hline Strongly Agree & 5 & 87 & \multirow{2}{*}{4.83} \\
\cline { 1 - 3 } Agree & 4 & 9 & \\
\cline { 1 - 3 } Neutral & 3 & 4 & \\
\cline { 1 - 3 } Disagree & 2 & $\mathrm{O}$ & \\
\cline { 1 - 3 } Strongly Disagree & 1 & $\mathrm{O}$ & \\
\hline
\end{tabular}

\section{NFBE school timing is according to need of children of} this community.
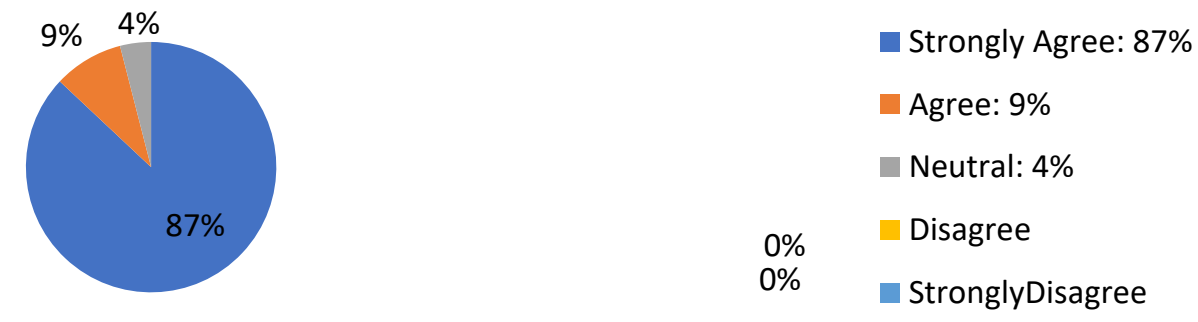
Teacher Accessibility

NFE teacher is available all the time for parents of children.

\begin{tabular}{|l|l|l|l|}
\hline Level & Value & Frequency & Mean \\
\hline Strongly Agree & 5 & 70 & \multirow{2}{*}{$4 \cdot 55$} \\
\cline { 1 - 2 } Agree & 4 & 20 & \\
\cline { 1 - 2 } Neutral & 3 & 5 & \\
\cline { 1 - 2 } Disagree & 2 & 5 & \\
\cline { 1 - 2 } Strongly Disagree & 1 & 0 & \\
\hline
\end{tabular}

\section{NFE teacher is available all the time for parents of children.}

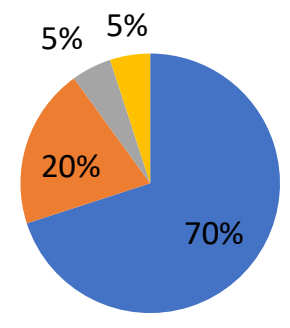

- Strongly Agree: $70 \%$

Agree: $20 \%$

Neutral: $5 \%$

Disagree: $5 \%$

$0 \%$

Community Participation:

Community members are involved and welcomed for improvement of school.

\begin{tabular}{|l|l|l|l|}
\hline Level & Value & Frequency & Mean \\
\hline Strongly Agree & 5 & 70 & \multirow{2}{*}{$4 \cdot 36$} \\
\cline { 1 - 2 } Agree & 4 & 9 & \\
\cline { 1 - 3 } Neutral & 3 & 10 & \\
\cline { 1 - 3 } Disagree & 2 & 6 & \\
\cline { 1 - 3 } Strongly Disagree & 1 & 4 & \\
\cline { 1 - 3 }
\end{tabular}

\section{Community members are involved and welcomed for improvement of school.}

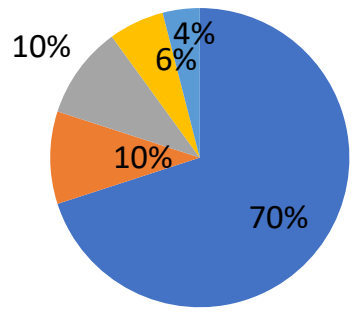

\footnotetext{
- Strongly Agree: 70\%

Agree: $10 \%$

Neutral: $10 \%$

- Strongly Disagree: 6\%

Disagree: $4 \%$
} 


\section{Multi-Grade Teaching}

Multi-grade teaching is adopted by teacher in NFBE School

\begin{tabular}{|l|l|l|l|}
\hline Level & Value & Frequency & Mean \\
\hline Strongly Agree & 5 & 51 & \multirow{2}{*}{$4 \cdot 3$} \\
\cline { 1 - 3 } Agree & 4 & 33 & \\
\cline { 1 - 3 } Neutral & 3 & 13 & \\
\hline Disagree & 2 & 1 & \\
\cline { 1 - 3 } Strongly Disagree & 1 & 2 & \\
\hline
\end{tabular}

\section{Multigrade teaching is adopted by teacher in NFBE school}

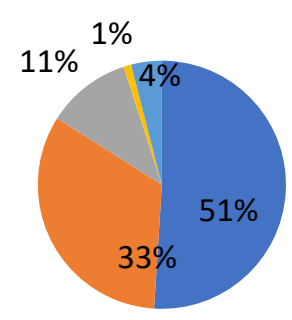

- Strongly Agree: 51\%

Agree: $33 \%$

Neutral: $11 \%$

Strongly Disagree: $1 \%$

Disagree: $4 \%$

\section{Results and Discussion}

This study investigated how a Non Formal Education System made sure educational access for marginalized communities through its strategies. Researcher used Questionnaires for data collection and used descriptive analysis for quantitative data. Following are key findings from data analysis followed by the conclusive statements.

\subsection{Findings:}

- Eighty (80\%) respondent were agreed that NFBE(Non formal basic Education) school are providing free of cost Education.

- According to 96\% respondent NFBE schools are accessible for all children in this community.

- $97 \%$ respondents preferred female teachers for NFBE schools.

- According to 96.0 percent respondents NFBE School is located in the center of this community.

- According to 90.0 percent respondents NFBE School are established at feasible sites on needbases.

- According to 96.0 percent respondents NFBE school timing is according to need of children of this community.

- According to 90.0 percent respondents NFE teacher is available all the time for parents of children.

- According to 80.0 percent respondents Community members are involved and welcomed for improvement of school.

- According to 84.0 percent respondent's Multi-grade teaching is adopted by teacher in NFBE School. 


\section{Conclusion}

It is concluded that there were several successful strategies that motivated the deprived communities towards education. These are the followings successful strategies:

It is concluded that organization provided total free of cost books, notebooks, pencils, bags, etc to ensure the educational access for deprived community It is also concluded that the learning environment was child friendly and clean and neat which attracted out of School children. Department had strict policy of inclusiveness following the international standards of education. Literacy \& NFBE department provided equal opportunities for the learners to live and learn together regardless of their culture, gender discrimination and physical and color differences.

It is concluded that about majority were the female teachers in Non Formal Education department, showing the department policy of recruiting the female teacher. This practice made possible educational access for out of School children specially girls of deprived community. Girls enrolment ratio has increased up to $55 \%$ in our Schools as compared to last 7 year. It is concluded from data analysis and findings that NFBE Schools were very useful alternative for those who could not afford formal Schools which were far from their homes due to transport expenditure.

NFE teacher was available for any query regarding child performance at all the time being local one. The parents appreciated the availability of teacher and literacy staff at any time for any enquiry regarding their children' educational performance or any other issue. This one also ensured the provision of education for marginalized communities. It is concluded that community participation is main focus of NFBE department to achieve the targets. It is concluded that Multi-grade Teaching method is adopted by teachers in NFBE School and ask to higher grade students to help learning process of other lower grade students

\section{Recommendation}

This study focused on strategies of Non Formal Basic Education Schools. Because this study was limited to only one organization therefore a similar but comparative study should be conducted using different approaches to examine the useful strategies which were emerged from this study. Researcher did not go inside the community due to COVID19. A future research should be conducted to explore the perceived benefits from school, such as how NFBES were shaping lives of people in deprived community. A longitudinal research should be conducted o graduates of NFBES to understand the transformation occurring in them. The study is limited to one department working under Government of Punjab. In fact 48 Organizations (Public/Private) also working in education sector of Non Formal Basic Education. It is not possible to involve all Organizations and Districts of Pakistan because of limited resources. So, it is recommended to conduct a study at large scale country wide to explore the role of Non Formal Basic Education in Pakistan.

\section{References}

United Nations Educational, Scientific and Cultural Organization. (2016). Education for people and planet: Creating sustainable futures for all. Paris, France: UNESCO.

United Nations General Assembly. (2015). Transforming our world: The 2030 agenda for sustainable development. Resolution adopted by the General Assembly.

United Nations International Children's Emergency Fund.(2013). Out-of-school children in the Balochistan, Khyber Pakhtunkhwa, Punjab and Sindh provinces of Pakistan. Islamabad: UNICEF Pakistan. 
United Nations Development Program, Pakistan. (2017). Pakistan national human development report 2017: Unleashing the potential of a young Pakistan. Retrieved from United Nations Development Programme (UNDP) website: http://hdr.undp.org/sites/default/files/ reports/2847/pk-nhdr.pdf United Nation International Children's Emergency Fund,(Evaluation Report February 2018; The out-ofSchool Children Initiative ).New York: UNICEF

Ministry of Education.(Pakistan Education Statistic 2016/2017).Academy of Educational Planning and Management, Islamabad: AEPAM.

Literacy \& Non Formal Basic Education Department Government of Punjab, Lahore: Punjab Literacy \& Non Formal Education Policy 2019:PLNFEP

Hussain, A., Salfi, N., \& Mahmood, T. (2011). Causes of students' dropout at primary level in Pakistan: An empirical study. International journal of humanities and social science, 1(12), 143-151.

Hitchcock, G., \& Hughes, D. (1995). Interviewing, asking question, \& conversations. In Research and the teacher: A qualitative introduction to school-based research (2nd ed., pp. 153-183). New York, NY: Routledge.

Creswell, J. W. (2003). Research design qualitative, quantitative and mix methods approaches (2nd ed.). London, UK: SAGE Publications Ltd. 